\title{
Phylogeography and systematics of the westernmost Italian Dolichopoda species (Orthoptera, Rhaphidophoridae)
}

\author{
Giuliana Allegrucci', Mauro Rampini², Claudio Di Russo², \\ Enrico Lana ${ }^{3}$, Sara Cocchi', Valerio Sbordoni'
}

I Dipartimento di Biologia, Università di Roma Tor Vergata, via della ricerca scientifica s.n.c. 00133 Rome, Italy 2 Dipartimento di Biologia e Biotecnologie "Charles Darwin", Università di Roma La Sapienza, Viale dell'Università 32, 00100 Rome, Italy 3 Gruppo Speleologico Piemontese (Torino) and Gruppo Speleologico Alpi Marittime (Cuneo)

Corresponding author: Giuliana Allegrucci (allegrucci@uniroma2.it)

Academic editor: Sam Heads | Received 16 May 2014 | Accepted 25 July 2014 | Published 28 August 2014

http://zoobank.org/70B61150-F710-4F97-A859-7419DE30FAD6

Citation: Allegrucci G, Rampini M, Di Russo C, Lana E, Cocchi S, Sbordoni V (2014) Phylogeography and systematics of the westernmost Italian Dolichopoda species (Orthoptera, Rhaphidophoridae). ZooKeys 437: 1-23. doi: 10.3897/ zookeys.437.7917

\begin{abstract}
The genus Dolichopoda (Orthoptera; Rhaphidopohoridae) is present in Italy with 9 species distributed from northwestern Italy (Piedmont and Liguria) to the southernmost Apennines (Calabria), occurring also in the Tyrrhenian coastal areas and in Sardinia. Three morphologically very close taxa have been described in Piedmont and Liguria, i.e., D. ligustica ligustica, D. ligustica septentrionalis and D. azami azami.

To investigate the delimitation of the northwestern species of Dolichopoda, we performed both morphological and molecular analyses. Morphological analysis was carried out by considering diagnostic characters generally used to distinguish different taxa, as the shape of epiphallus in males and the subgenital plate in females. Molecular analysis was performed by sequencing three mitochondrial genes, $12 \mathrm{~S}$ rRNA, $16 \mathrm{~S}$ rRNA, partially sequenced and the entire gene of COI.
\end{abstract}

Copyright Giuliana Allegrucci et al. This is an open access article distributed under the terms of the Creative Commons Attribution License (CC BY 4.0), which permits unrestricted use, distribution, and reproduction in any medium, provided the original author and source are credited. 
Results from both morphological and molecular analyses highlighted a very homogeneous group of populations, although genetically structured. Three haplogroups geographically distributed could be distinguished and based on these results we suggest a new taxonomic arrangement. All populations, due to the priority of description, should be assigned to D. azami azami Saulcy, 1893 and to preserve the names ligustica and septentrionalis, corresponding to different genetic haplogroups, we assign them to D. azami ligustica Baccetti \& Capra, 1959, stat. n. and to D. azami septentrionalis Baccetti \& Capra, 1959, stat. n.

\section{Keywords}

Westernmost Dolichopoda species, barcoding, systematics

\section{Introduction}

Dolichopoda is a Mediterranean genus, consisting of more than fifty species distributed throughout the North Mediterranean regions from the Pyrenees to Transcaucasia and north Iran (Di Russo and Rampini 2014). The highest species diversity is present in insular and peninsular Greece where most of the species have been described (Di Russo et al. 2007). However, many species are present also in Italy. In particular, nine species of Dolichopoda occur in Italy, where they range from the Maritime Alps to the southern tip of the Italian peninsula, excluding the oriental Alps, the Liguria Apennines, the Apuane Alps and the southern Apulia. Most species of this genus are strictly dependent upon caves. However, especially in the northern part of the range, several populations inhabit cave-like habitat such as rock-crevices and ravines and individuals can be observed, during the night, outside in moist or mesic woods. In peninsular Italy, Dolichopoda populations often live in cellars, catacombs, aqueducts, Etruscan tombs and other similar man-made hypogean environments. Population sizes can be small and constant over long periods, at least in natural caves (Carchini et al. 1983; Sbordoni et al. 1987).

Based on morphology three subgenera have been described in Italy: Dolichopoda (Dolichopoda), D. (Chopardina) and D. (Capraiacris) (Baccetti 1975; Baccetti and Capra 1959, 1970). One of the main morphological differences between these subgenera is presence or absence of spinulation on the legs. The subgenus Dolichopoda includes the highest number of species distributed throughout the range of the genus, except for some coastal areas and it is characterized by the presence of spines on the anterior tibiae. Species belonging to Chopardina sub-genus are mostly found in insular and peninsular Tuscany and Sardinia in Italy and in Corsica, with two other species found in Greece (Macedonia and Etolia Akarnania). Chopardina species are characterized by the presence of several spines also on the hind femurs. The subgenus Capraiacris includes only two species, restricted to the Giglio Island and Monte Argentario in the Tuscan archipelago. Its two species $(D$. aegilion and $D$. baccettii) are distinct from all the other species because of the lack of spines on the anterior tibiae and on the hind femur. However, studies based on molecular characters did not support the subdivision in sub-genera, showing that the subgenus Chopardina is polyphyletic and the subgenus 
Dolichopoda is paraphyletic (Allegrucci et al. 2005). Since the main morphological character defining the subgenera is the presence/absence of spines on the appendages, Allegrucci et al. (2005) concluded that such character is an adaptive character subject to homoplasy. Based on these observations we decided to not consider the subdivision in sub-genera of the species belonging to genus Dolichopoda.

Based on molecular phylogenetic reconstruction (Allegrucci et al. 2005; 2009; 2011) the current distribution of Dolichopoda species has been essentially shaped by the palaeogeographic and climatic events occurred in the Mediterranean region, starting from Late Miocene. However, also adaptation to cave life seems to have played an important role in this process. In particular, the end of Messinian salinity crisis would mark the geographic separation of the epigean forest populations and the beginning of dispersal toward the west Mediterranean region. The migration and /or the isolation of the different insular populations might have also been favored by marine regressions and transgressions, during the Plio-Pleistocene. This era has been also characterized by climatic shifts during alternating glacial and interglacial periods. The sylvicolous ancestors of Dolichopoda might have used caves as refugia during the unfavorable climatic conditions, beginning their adaptation to subterranean habitat. Therefore, the current distribution of Dolichopoda can be explained by a combination of both vicariance and dispersal events, with many processes occurring in ancestral epigean populations before the invasion of the subterranean environment.

The most western Italian species are represented by D. ligustica, and D. azami. Two subspecies are attributed to D. ligustica, i.e., D. ligustica ligustica and D. l. septentrionalis. The first one is widespread in the Southern Piedmont (Maritime Alps) and in the north-western Liguria while the range of D. l. septentrionalis is northernmost and limited to a small area in Val di Lanzo valley, close to Turin, and in some easternmost caves, close to Bergamo. D. azami Saulcy, 1893 is widespread in the south eastern France and observed also in Piedmont in a cave in Grana Valley (Baccetti and Capra 1959). The systematic position of D. azami has long been discussed (Finot 1890; Azam 1893; Chopard 1922, 1951) until Baccetti (1966) reclassified the systematics of the western Dolichopoda species, based on the morphology of the epiphallus and of the tergum 10, the most important characters for the systematics of the genus Dolichopoda.

D. ligustica and $D$. azami have very similar morphologies with little variation in the characters on which the systematics are based. To better understand the differentiation between these two species and the limits of the ranges occupied by each of them, we carried out a study on several populations of D. ligustica and D. azami, both at morphological and molecular levels. The main aims of this study are: i) to infer the phylogenetic relationships of these two species, using molecular markers; ii) to compare their differentiation with the differentiation of all other species belonging to genus Dolichopoda previously analyzed (Allegrucci et al. 2005, 2009, 2011); iii) to revise the taxonomic arrangement of species and subspecies based on both morphological and molecular characters. 


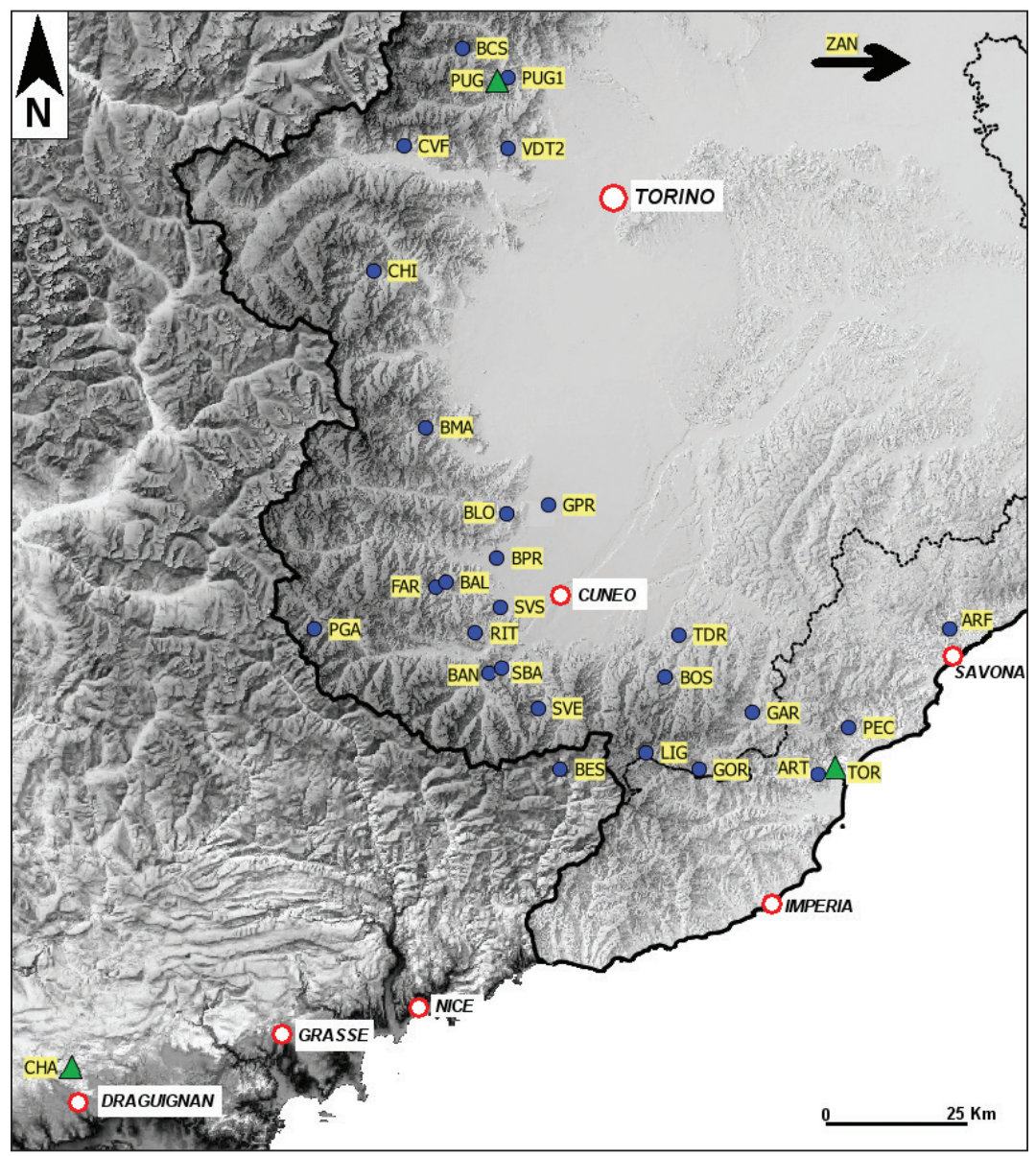

Figure I. Sampling sites of Dolichopoda populations considered in this study (see also Table 1). Triangles indicate the type locality of the three considered taxa (CHA: D. azami, TOR: D. l. ligustica, PUG: D. l. septentrionalis).

\section{Materials and methods}

\section{Taxon sampling and laboratory procedures}

A total of 26 populations from Piedmont and Liguria (Maritime Alps, and western Liguria Apennines in northwest Italy), were analyzed in this study (Fig. 1, Table 1).

DNA was isolated from leg muscle of each individual, using a GenElute Mammalian Genomic DNA minipreparation Kit (Sigma-Aldrich, St. Louis, MO, USA) resuspended in $200 \mu \mathrm{l}$ of sterile water and stored at $-40{ }^{\circ} \mathrm{C}$.

The entire Cytochrome Oxidase I gene (COI, total of 1500 bp), a 550-bp fragment of the 16S rRNA gene, a 450-bp fragment of the 12S rRNA gene and were amplified through the polymerase chain reaction (PCR) and sequenced from each individual. 
Table I. North Western Italian Dolichopoda sampled in this study. All populations were analyzed at molecular level, while only the populations in which adults were present, were analyzed also at morphological level.

\begin{tabular}{|c|c|c|c|c|}
\hline Taxon & Localities and sample size & Code & 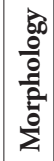 & GenBank Accession No. \\
\hline D. azami & $\begin{array}{l}\text { Mine close to Chauves-souris Cave, } \\
\text { Chateaudouble, Var, France, type locality, } \\
525 \text { m asl; Sampled individuals: } 3\end{array}$ & $\mathrm{CHA}$ & $\mathrm{X}$ & $\begin{array}{l}\text { 12S: KM086460; 16S: KM086485; } \\
\text { COI: KM086535; 28S: KM086510 }\end{array}$ \\
\hline \multirow[t]{2}{*}{ D.l. ligustica } & $\begin{array}{l}\text { Taragnina Cave, Balestrino, SV, Liguria, close } \\
\text { to Santa Lucia Inferiore Cave, } 310 \mathrm{~m} \text { asl; } \\
\text { Sampled individuals: } 5\end{array}$ & ART & & $\begin{array}{l}\text { 12S: KM086464; 16S: KM086489; } \\
\text { COI: KM086539; 28S: KM086514 }\end{array}$ \\
\hline & $\begin{array}{l}\text { Santa Lucia Inferiore Cave, Toirano, SV, } \\
\text { Liguria, type locality, } 194 \mathrm{~m} \text { asl }\end{array}$ & TOR & $\mathrm{X}$ & \\
\hline D. l. septentrionalis & $\begin{array}{l}\text { Borna Maggiore del Pugnetto Cave, } \\
\text { Mezzenile, Lanzo Valley, TO, Piedmont, type } \\
\text { locality, } 820 \text { m asl; Sampled individuals : } 8\end{array}$ & PUG & $\mathrm{X}$ & $\begin{array}{l}\text { 12S: KM086474; 16S: KM086499; } \\
\text { COI: KM086549; 28S: KM086524 }\end{array}$ \\
\hline \multirow{14}{*}{ Dolichopoda sp. } & Tana del Peccetto Cave, Magliolo, SV & PEC & $\mathrm{X}$ & \\
\hline & $\begin{array}{l}\text { Besta Cave, Vievola, Tenda, France, } 910 \mathrm{~m} \\
\text { asl; Sampled individuals: } 2\end{array}$ & BES & $\mathrm{X}$ & $\begin{array}{l}\text { 12S: KM086459; 16S: KM086484; } \\
\text { COI: KM086534; 28S: KM086509 }\end{array}$ \\
\hline & $\begin{array}{l}\text { Falconiere Cave, Garessio,CN, Piedmont, } \\
1000 \mathrm{~m} \text { asl }\end{array}$ & GAR & $\mathrm{X}$ & \\
\hline & $\begin{array}{l}\text { Orso Cave, Ponte di Nava, Ormea, CN, } \\
\text { Piedmont, } 808 \mathrm{~m} \text { asl; Sampled individuals: } 3\end{array}$ & GOR & & $\begin{array}{l}\text { 12S: KM086472; 16S: KM086497; } \\
\text { COI: KM086547; 28S: KM086522 }\end{array}$ \\
\hline & $\begin{array}{l}\text { Viozene, Ormea, upper Tanaro Valley, CN, } \\
\text { Piedmont (epigean), } 1250 \mathrm{~m} \text { asl; Sampled } \\
\text { individuals: } 2\end{array}$ & LIG & & $\begin{array}{l}\text { 12S: KM086470; 16S: KM086495; } \\
\text { COI: KM086545; 28S: KM086520 }\end{array}$ \\
\hline & $\begin{array}{l}\text { Vernante hypogeum, Vernante, Vermenagna } \\
\text { Valley, CN, Piedmont, } 800 \mathrm{~m} \text { asl; Sampled } \\
\text { individuals: } 5\end{array}$ & SVE & $\mathrm{X}$ & $\begin{array}{l}\text { 12S: KM086458; 16S: KM086483; } \\
\text { COI: KM086533; 28S: KM086508 }\end{array}$ \\
\hline & $\begin{array}{l}\text { Bossea Cave, Frabosa Soprana, Corsaglia } \\
\text { Valley, CN, Piedmont, } 836 \text { m asl; Sampled } \\
\text { individuals: } 2\end{array}$ & BOS & $\mathrm{X}$ & $\begin{array}{l}\text { 12S: KM086465; 16S: KM086490; } \\
\text { COI: KM086540; 28S: KM086515 }\end{array}$ \\
\hline & $\begin{array}{l}\text { Arma de Faie Cave, Albissola, Sansobbia } \\
\text { Valley, SV, Liguria, } 624 \mathrm{~m} \text { asl }\end{array}$ & ARF & $\mathrm{X}$ & \\
\hline & $\begin{array}{l}\text { Bandito Cave, Valdieri, Gesso Valley, CN, } \\
\text { Piedmont, } 726 \text { m asl; Sampled individuals: } 2 \\
\end{array}$ & BAN & $\mathrm{X}$ & $\begin{array}{l}\text { 12S: KM086471; 16S: KM086496; } \\
\text { COI: KM086546; 28S: KM086521 }\end{array}$ \\
\hline & $\begin{array}{l}\text { Bandito hypogeum, Roaschia, Gesso } \\
\text { Valley, CN, Piedmont, } 730 \text { m asl; Sampled } \\
\text { individuals: } 7\end{array}$ & SBA & $\mathrm{X}$ & $\begin{array}{l}\text { 12S: KM086463; 16S: KM086488; } \\
\text { COI: KM086538; 28S: KM086513 }\end{array}$ \\
\hline & $\begin{array}{l}\text { Dronera Cave, Vicoforte Mondovì, Ermetta } \\
\text { Valley, CN, Piedmont, } 525 \text { m asl; Sampled } \\
\text { individuals: } 6\end{array}$ & TDR & $\mathrm{X}$ & $\begin{array}{l}\text { 12S: KM086468; 16S: KM086493; } \\
\text { COI: KM086543; 28S: KM086518 }\end{array}$ \\
\hline & $\begin{array}{l}\text { Rittana Cave, Rittana, Stura di Demonte } \\
\text { Valley, CN, Piedmont, } 1000 \text { m asl; Sampled } \\
\text { individuals: } 3\end{array}$ & RIT & $\mathrm{X}$ & $\begin{array}{l}\text { 12S: KM086467; 16S: KM086492; } \\
\text { COI: KM086542; 28S: KM086517 }\end{array}$ \\
\hline & $\begin{array}{l}\text { Vallone Saben eastern hypogeum, Valdieri, } \\
\text { Gesso Valley, CN, Piedmont, } 750 \mathrm{~m} \text { asl; } \\
\text { Sampled individuals: } 6\end{array}$ & SVS & $\mathrm{X}$ & $\begin{array}{l}\text { 12S: KM086462; 16S: KM086487; } \\
\text { COI: KM086537; 28S: KM086512 }\end{array}$ \\
\hline & $\begin{array}{l}\text { Gaiola Cave, Gaiola, Stura di Demonte } \\
\text { Valley, CN, Piedmont, } 1020 \mathrm{~m} \text { asl; Sampled } \\
\text { individuals: } 3\end{array}$ & PGA & $\mathrm{X}$ & $\begin{array}{l}\text { 12S: KM086457; 16S: KM086482; } \\
\text { COI: KM086532; 28S: KM086507 }\end{array}$ \\
\hline
\end{tabular}




\begin{tabular}{|c|c|c|c|}
\hline \begin{tabular}{|l|} 
Farout Cave, Pradleves, Grana Valley, CN, \\
Piedmont, $1050 \mathrm{~m}$ asl; Sampled individuals: 3 \\
\end{tabular} & FAR & $\mathrm{X}$ & $\begin{array}{l}\text { 12S: KM086461; 16S: KM086486; } \\
\text { COI: KM086536; 28S: KM086511 }\end{array}$ \\
\hline $\begin{array}{l}\text { Balmarossa Cave, Pradleves, Grana Valley, } \\
\text { CN, Piedmont, } 1180 \text { m asl; Sampled } \\
\text { individuals: } 2\end{array}$ & BAL & $\mathrm{X}$ & $\begin{array}{l}\text { 12S: KM086452; 16S: KM086477; } \\
\text { COI: KM086527; 28S: KM086502 }\end{array}$ \\
\hline $\begin{array}{l}\text { Buco del Partigiano Cave, Roccabruna, Maira } \\
\text { Valley, CN, Piedmont, } 1100 \mathrm{~m} \text { asl; Sampled } \\
\text { individuals: } 7\end{array}$ & BPR & & $\begin{array}{l}\text { 12S: KM086455; 16S: KM086480; } \\
\text { COI: KM086530; 28S: } \\
\text { KM086505; }\end{array}$ \\
\hline \begin{tabular}{|l|} 
Partigiani Cave, Rossana, Varaita Valley, CN, \\
Piedmont, 615 m asl; Sampled individuals: 8 \\
\end{tabular} & GPR & $\mathrm{X}$ & $\begin{array}{l}\text { 12S: KM086469; 16S: KM086494; } \\
\text { COI: KM086544; 28S: KM086519 }\end{array}$ \\
\hline $\begin{array}{l}\text { Buco delle Locuste Cave, Pagliano, Varaita } \\
\text { Valley, CN, Piedmont, } 595 \text { m asl; Sampled } \\
\text { individuals: } 2\end{array}$ & BLO & $\mathrm{X}$ & $\begin{array}{l}\text { 12S: KM086466; 16S: KM086491; } \\
\text { COI: KM086541; 28S: KM086516 }\end{array}$ \\
\hline $\begin{array}{l}\text { Buco del Maestro Cave, Paesana, Po Valley, } \\
\text { CN, Piedmont, } 750 \text { m asl; Sampled } \\
\text { individuals: } 6\end{array}$ & BMA & & $\begin{array}{l}\text { 12S: KM086453; 16S: KM086478; } \\
\text { COI: KM086528; 28S: } \\
\text { KM086503; }\end{array}$ \\
\hline $\begin{array}{l}\text { Chiabrano Cave, Perrano, Germanasca } \\
\text { Valley, TO, Piedmont, } 1080 \mathrm{~m} \text { asl; Sampled } \\
\text { individuals: } 6\end{array}$ & $\mathrm{CHI}$ & $\mathrm{X}$ & $\begin{array}{l}\text { 12S: KM086456; 16S: KM086481; } \\
\text { COI: KM086531; 28S: KM086506 }\end{array}$ \\
\hline $\begin{array}{l}\text { Villar Focchiardo Cave, Villar Focchiardo, } \\
\text { Susa Valley, TO, Piedmont, } 460 \mathrm{~m} \text { asl; } \\
\text { Sampled individuals: } 6\end{array}$ & CVF & & $\begin{array}{l}\text { 12S: KM086473; 16S: KM086498; } \\
\text { COI: KM086548; 28S: KM086523 }\end{array}$ \\
\hline $\begin{array}{l}\text { Val della Torre Mine, Val della Torre, } \\
\text { Casternone Valley, TO, Piedmont, } 840 \mathrm{~m} \text { asl; } \\
\text { Sampled individuals: } 5\end{array}$ & VDT2 & & $\begin{array}{l}\text { 12S: KM086475; 16S: KM086500; } \\
\text { COI: KM086550; 28S: KM086525 }\end{array}$ \\
\hline \begin{tabular}{|l|} 
Wolf Cave, Mezzenile, Lanzo Valley TO, \\
Piedmont, $813 \mathrm{~m}$ asl; Sampled individuals: 4 \\
\end{tabular} & PUG1 & $\mathrm{X}$ & Same as PUG \\
\hline $\begin{array}{l}\text { Borna del Servais Cave, Ala di Stura, Ala } \\
\text { Valley, TO, Piedmont, } 1440 \mathrm{~m} \text { asl; Sampled } \\
\text { individuals: } 2\end{array}$ & BCS & & $\begin{array}{l}\text { 12S: KM086454; 16S: KM086479; } \\
\text { COI: KM086529; 28S: } \\
\text { KM086504; }\end{array}$ \\
\hline \begin{tabular}{|l|} 
Lacca Selva Cave, Zandobbio, BG, \\
Lombardy, 340 m asl; Sampled individuals: 2 \\
\end{tabular} & ZAN & $\mathrm{X}$ & $\begin{array}{l}\text { 12S: KM086476; 16S: KM086501; } \\
\text { COI: KM086551; 28S: KM086526 }\end{array}$ \\
\hline
\end{tabular}

The large subunit of the nuclear ribosomal DNA ( $28 \mathrm{~S}$ rRNA) was also included. The primers used were: LCO1490, HCO 2198 (Folmer et al. 1994), UEA1, UEA5 and UEA10 (Lunt et al. 1996) for the COI gene, 12Sai, 12Sbi (Kocher et al. 1989; Simon et al. 1994) for the 12S rRNA gene and 16Sar, 16Sbr (Simon et al. 1994) for the $16 \mathrm{~S}$ gene. 28S rRNA was partially amplified and sequenced for a fragment of 580 base pairs, belonging to domains 3-5, using primers from Friedrich and Tautz (1997). Double-stranded amplifications were performed with a Perkin-Elmer-Cetus thermal cycler in $25 \mu \mathrm{l}$ reaction volume containing genomic DNA (10-100 ng), $1.5 \mathrm{mM}$ $\mathrm{MgCl} 2,0.2 \mathrm{mM}$ of each dNTP, $0.1 \mu \mathrm{M}$ primer, 1.5 units EuroTaq (Euroclone, UK) and the buffer supplied by the manufacturer. Optimal cycling parameters varied for each primer pair used. PCR products were purified using the ExoSAP digestion (Amersham Pharmacia Biotech), directly sequenced in both directions using the BigDye terminator ready-reaction kit, and resolved on ABI 3100 Genetic Analyzer (PE Applied Biosystems), following the manufacturer's protocols. Sequence data were edited 
and compiled using CodonCode Aligner (version 3.7.1). All sequences were submitted to GenBank (Accession Numbers are reported in Table 1).

Each gene fragment (12S, 16S, COI and 28S) was considered separately for the alignment. Sequences of 16S, 12S and 28S were aligned using CLUSTAL_X 1.81 (Thompson et al. 1997) with opening gap $=10$ and extending gap $=0.10$. Cytochrome oxidase I nucleotide sequences were assembled, aligned, and translated with Codon-Code Aligner 3.7.1.

\section{Data analysis}

\section{Genetic differentiation and structure in the westernmost Dolichopoda species}

Haplotype and nucleotide diversity were calculated using DNASP 5.10 (Rozas et al. 2003). Genetic distances between haplotypes and between groups of haplotypes were calculated using p-distance as implemented in MEGA 5.2 (Tamura et al. 2007). NETWORK 4.502 (Bandelt et al. 1999) was employed to calculate a median joining network representing the genealogical relationships among mtDNA haplotypes.

A Mantel test (Mantel 1967) with 5,000 simulations was used to test for an isolation-by-distance (IBD) signature (a positive correlation between geographic and genetic distances; Wright 1943; Slatkin 1993).

The hierarchical distribution of genetic variation was characterized using analysis of molecular variance (AMOVA). This method apportions genetic variation within and among groups, estimating F-statistics (Weir and Cockerham 1984; Excoffier et al. 1992; Weir 1996) that are analogous to Wright's hierarchical fixation indices under the island model of gene flow (Wright 1951). Three-level AMOVA was conducted in ARLEQUIN 3.5.1.2 (Excoffier et al. 1992; Excoffier et al. 2005) using an $F_{\mathrm{ST}}$-like estimator. Samples were partitioned by geographic regions, populations within geographic regions, and populations. These tests included permutation of inferred haplotypes among groups $\left(F_{\mathrm{CT}}\right)$; individual haplotypes among populations but within group $\left(F_{\mathrm{SC}}\right)$; inferred haplotypes among populations $\left(F_{\mathrm{ST}}\right)$.

\section{Species delimitation and phylogenetic analysis}

Species delimitation analysis was carried out with two methods, a) the "classical" DNA barcoding gap analysis (Hebert et al. 2003) and b) the Automatic Barcode Gap Discovery (ABGD, Puillandre et al. 2012). Both analyses were carried on the present samples and all Dolichopoda species previously analyzed (Table 2 and Allegrucci et al. 2005, 2011; Martinsen et al. 2009), considering only COI data set and only the common base pairs consisting of 964 bp. The "classical" DNA barcoding gap analysis was based on the pairwise genetic distances ( $p$-distance). Distribution of genetic distance values was analyzed at different taxonomic levels. 
Table 2. Species, populations, localities and accession numbers to GenBank for the Dolichopoda sequences included in this study and retrieved from GenBank for phylogenetic reconstruction of the western Mediterranean Dolichopoda species (Data from Allegrucci et al. 2005, 2009, 2011 and Martinsen et al. 2009).

\begin{tabular}{|c|c|c|}
\hline Taxon & Localities & GenBank Accession No. \\
\hline \multicolumn{3}{|l|}{ Outgroup } \\
\hline \multirow{2}{*}{ Euhadenoecus insolitus } & Indian Grave Point Cave (IND), De & 12S: EF216947; 16S: AY793563; \\
\hline & Kalb Co., TN, USA & COI: AY793591; 28S: EF217005 \\
\hline \multirow{2}{*}{$\begin{array}{l}\text { Hadenoecus cumber- } \\
\text { landicus }\end{array}$} & Bat Cave (BAT), Carter Cave State & 12S: EF216948; 16S: AY793562; \\
\hline & Park, Carter Co., KY, USA & COI: AY793592; 28S: EF217004 \\
\hline \multirow{2}{*}{ Troglophilus cavicola } & Covoli di Velo Cave (TRO), Veneto, & 12S: EF216946; 16S: AY793564; \\
\hline & Northern Italy & COI: AY793624; 28S: EF217003 \\
\hline \multicolumn{3}{|l|}{ Ingroup } \\
\hline D. bolivari & $\begin{array}{l}\text { Forat negre Cave, Serra del Llerida, } \\
\text { Pyrenees, Spain }\end{array}$ & 16S: AY507579-80, COI: AY507648-49 \\
\hline D. linderi & $\begin{array}{l}\text { Sirach Cave (SIR) Eastern Pyrenees, } \\
\text { Western-South France }\end{array}$ & $\begin{array}{l}\text { 12S: JF826039; 16S: AY793567; } \\
\text { COI: AY793598-99; 28S: JF826069 }\end{array}$ \\
\hline \multirow{3}{*}{ D. laetitiae } & $\begin{array}{l}\text { Poscola Cave (PSC), Veneto, North- } \\
\text { ern-East Italy }\end{array}$ & $\begin{array}{l}\text { 12S: JF826054; 16S: AY793581; } \\
\text { COI: AY793611 and 13; 28S: JF826076 }\end{array}$ \\
\hline & $\begin{array}{l}\text { Piane Cave (GDP), Umbria, Central } \\
\text { Italy }\end{array}$ & $\begin{array}{l}\text { 12S: JF826053; 16S: AY793582; } \\
\text { COI: AY793610 and 12; 28S: JF826075 }\end{array}$ \\
\hline & $\begin{array}{l}\text { Diavolo Cave (DIA), Tuscany, Cen- } \\
\text { tral Italy }\end{array}$ & $\begin{array}{l}\text { 12S: JF826052; 16S: AY793580; } \\
\text { COI: AY793614-15; 28S: JF826074 }\end{array}$ \\
\hline \multirow{6}{*}{ D. geniculata } & Valmarino Cave (VAL), Latium, & 12S: JF826055; 16S: AY793583; \\
\hline & Central-South Italy & COI: AY793616-17; 28S: JF826077 \\
\hline & Fontanelle Cave (FON), Campania, & 12S: JF826057; 16S: AY793584; \\
\hline & Southern-West Italy & COI: AY793594; 28S: JF826079 \\
\hline & $\begin{array}{l}\text { Iscnia cellars (ISC), Iscnia Island, } \\
\text { Campania, Southern-West Italy }\end{array}$ & $\begin{array}{l}\text { 120: JF820058; 10S: AY/9538); } \\
\text { COI: AY793595; 28S: JF826080 }\end{array}$ \\
\hline & $\begin{array}{l}\text { Roman Aqueduct (PNZ), Ponza } \\
\text { Island, Latium, Southern-West Italy }\end{array}$ & 16S: AY793586; COI: AY793596-97 \\
\hline \multirow[t]{2}{*}{ D. capreensis } & San Michele Cave (CPR), Capri Is- & 12S: JF826059; 16S: AY793587; \\
\hline & land, Campania, Southern Italy & COI: AY793606-7; 28S: JF826081 \\
\hline D. palpata & $\begin{array}{l}\text { Tremusa cave (TRE), Calabria, } \\
\text { Southern Italy }\end{array}$ & $\begin{array}{l}\text { 12S: JF826060; 16S: AY793588; } \\
\text { COI: AY793608-9; 28S: JF826082 }\end{array}$ \\
\hline D. baccettii & $\begin{array}{l}\text { Punta degli Stretti Cave (PST), Tus- } \\
\text { cany, Central-West Italy, }\end{array}$ & $\begin{array}{l}\text { 12S: JF826046; 16S: AY793571; } \\
\text { COI: AY793639-40; 28S: JF826068 }\end{array}$ \\
\hline \multirow{2}{*}{ D. aegilion } & Campese Mine (CAM), Giglio Is- & 12S: JF826045; 16S: AY793570; \\
\hline & land, Tuscany, Central-West Italy & COI: AY793600; 28S: JF826067 \\
\hline \multirow{5}{*}{ D. schiavazzii } & $\begin{array}{l}\text { Pipistrelli Cave (ORS), Tuscany, } \\
\text { Central-West Italy }\end{array}$ & $\begin{array}{l}\text { 12S: JF826044; 16S: AY793573; } \\
\text { COI. AY793633: 28S. JF826066 }\end{array}$ \\
\hline & Marciana Cave (MRC), Elba Island, & 12S: JF826043; 16S: AY793572; \\
\hline & Tuscany, Central-West Italy & COI: AY793635; 28S: JF826065 \\
\hline & Fichino Cave (FIC), Tuscany, Cen- & 12S: JF826042; 16S: AY793574; \\
\hline & $\begin{array}{l}\text { tral-West Italy } \\
\text { Brando Cave (BRA) Corsica Island }\end{array}$ & COI: AY793634-36; 28S: JF8260C \\
\hline \multirow{2}{*}{ D. bormansi } & $\begin{array}{l}\text { Brando Cave (BRA), Corsica Island, } \\
\text { France }\end{array}$ & $\begin{array}{l}\text { 12S: JF826047; 16S: AY793578; } \\
\text { COI: AY793627 and 31-32; 28S: } \\
\text { JF826069 }\end{array}$ \\
\hline & $\begin{array}{l}\text { Sisco Cave (SIS), Corsica Island, } \\
\text { France }\end{array}$ & $\begin{array}{l}\text { 12S: JF826048; 16S: AY793579; } \\
\text { COI: AY793625-26 and 28; 28S: } \\
\text { JF826070 }\end{array}$ \\
\hline
\end{tabular}




\begin{tabular}{l|l|l}
\hline \multirow{3}{*}{ D. cymensis } & Valletto Cave (VLT), Corsica Island, & 12S: JF826050; 16S: AY793577; \\
& COI: AY793620-21; 28S: JF826072 \\
\cline { 2 - 3 } & Sabara Cave (SAB), Corsica Island, & 12S: JF826049; 16S: AY793576; \\
& COI: AY793618-19; 28S: JF826071 \\
\hline \multirow{2}{*}{ F. muceddai } & Limbara Mount, Sardinia Island, Italy & $\begin{array}{l}\text { 12S: JF826051; 16S: AY793575; } \\
\text { COI: AY793629-30; 28S: JF826073 }\end{array}$ \\
\hline
\end{tabular}

The ABGD method (Puillandre et al. 2012) automatically finds the distance at which a barcode gap occurs and sorts the sequences into putative species based on this distance. The method statistically infers the barcode gap from the data and partitions the data accordingly. Populations belonging to the same species therefore should be grouped in the same partition. This procedure is then recursively applied to the previously obtained groups of sequences. COI alignments were uploaded at http://wwwabi. snv.jussieu.fr/public/abgd/abgdweb.html and ABGD was run with the default settings $(P \min =0.001, P \max =0.1$, Steps $=10, \mathrm{X}($ relative gap width $)=1.5, \mathrm{Nb}$ bins $=20)$ and using $\mathrm{p}$-distance.

A phylogenetic analysis was carried out considering the four sequenced genes, by constructing a concatenated matrix, partitioned by genes. Phylogenetic analysis was performed only on the western Mediterranean Dolichopoda species, using Bayesian inferences as implemented by the software MrBayes 3.1b4 (Huelsenbeck and Ronquist 2001). Mrmodel test (Nylander 2004) was used to perform hierarchical likelihood ratio test and calculate approximate Akaike Information Criterion (AIC) values of the nucleotide substitution models for each gene fragment.

At least two simultaneous searches were conducted comprising four Markov chains started from a randomly chosen tree and run for 1,000,000 generations, with sampling every 100 generations. The following descriptors were assumed to indicate convergence on a common phylogenetic topology by separate Bayesian searches: similarity in $\log$ likelihood scores at stationarity, similarity in consensus tree topologies and PP values for supported nodes, and a final average standard deviation of split frequencies (ASDSF) for simultaneous searches approaching zero. The first 1,000 trees were discarded as burn-in and posterior probabilities (PP) were calculated from post burn-in trees.

\section{Morphological analysis}

The most important morphological characters used in the systematics of the genus Dolichopoda are the shape of the epiphallus and of the male tergum 10. In this study, the investigation of these characters was integrated by the analysis of other morphological features as male sub-genital plate, female sub-genital plate and shape of ovipositor.

Overall, we have checked 22 populations from the northwestern Italy for a total of 64 adult individuals. All these populations are the same analyzed for the genetic varia- 
tion (Table 1). Further comparisons were made using three more samples (PEC, ARF, GAR) coming from the collection of Museum of Natural History of Genoa G. Doria. The specimens were studied using a stereomicroscope Leica MZ 12.5. All the measures of the morphological parameters are in $\mathrm{mm}$. Photos were taken with a digital camera, Nikon Coolpix P300. Pictures were processed using a digitiser board WACOM CTH 461 and Adobe Photoshop CS3 Extended Version 10.0.

Table 3 shows the measures of twelve morphological characters in 6 populations where a sufficient number of adults were available. In particular, we considered the total body length, the pronotum length, and the length of tarsum, femur and tibia of the fore, middle and hind legs in both males and females and the ovipositor length in females. Measurements were taken using a digital caliper (accuracy $0.01 \mathrm{~mm}$ ). Morphometric variables were analyzed by using the non-parametric ANOVA Kruskal-Wallis test. A multiple regression analysis was carried out comparing morphometric variables with the altitude of the caves.

\section{Results}

\section{Genetic differentiation and structure in the westernmost Dolichopoda species}

A total of 2450 mitochondrial base pairs corresponding to the entire COI gene, to 450 bp of $12 S$ and $550 \mathrm{bp}$ of $16 \mathrm{~S}$ were successfully sequenced and aligned in 104 specimens of Dolichopoda populations from northwestern Italy. $28 \mathrm{~S}$ rRNA, consisting of $500 \mathrm{bp}$ was also sequenced in all considered samples. Ribosomal genes were identical in all assayed samples. Therefore, the analysis was limited to the COI mitochondrial gene.

The 104 individual COI sequences comprised a total of 15 haplotypes determined by 13 segregating sites. Global haplotype diversity, $h$, was 0.875 and nucleotide diversity, $p$, was 0.00231 .

Dolichopoda haplotypes were organized in three main haplogroups in which haplotypes are ordered geographically (Fig. 2). In particular, haplogroup 1 included samples from the northernmost area, haplogroup 2 samples from the westernmost area and haplogroup 3 consisted of samples from the south-eastern area (Fig.2).

To investigate this further we carried out a genetic distance analysis using COI gene as a barcode and p-distance between all studied Dolichopoda species (Allegrucci et al. 2005, 2009, 2011; Martinsen et al. 2009). Genetic distance values at intra- and interspecific levels are compared in Figure 3. In particular, Figure 3 shows the genetic distance values found in intra- and interspecific comparisons of all studied Dolichopoda species compared to the interspecific values found in comparisons between the northwestern Italian populations. Intraspecific values between all Dolichopoda species ranged from 0 to 0.023 , with a mean of $0.001( \pm 0.0019$, standard deviation), while interspecific values ranged from 0.016 to 0.134 , with a mean of $0.134( \pm 0.020$, standard deviation). Pairwise comparisons between the northwestern Italian populations ranged from 0 to 0.007 with a mean of 0.003 ( \pm 0.0015 , standard deviation). 


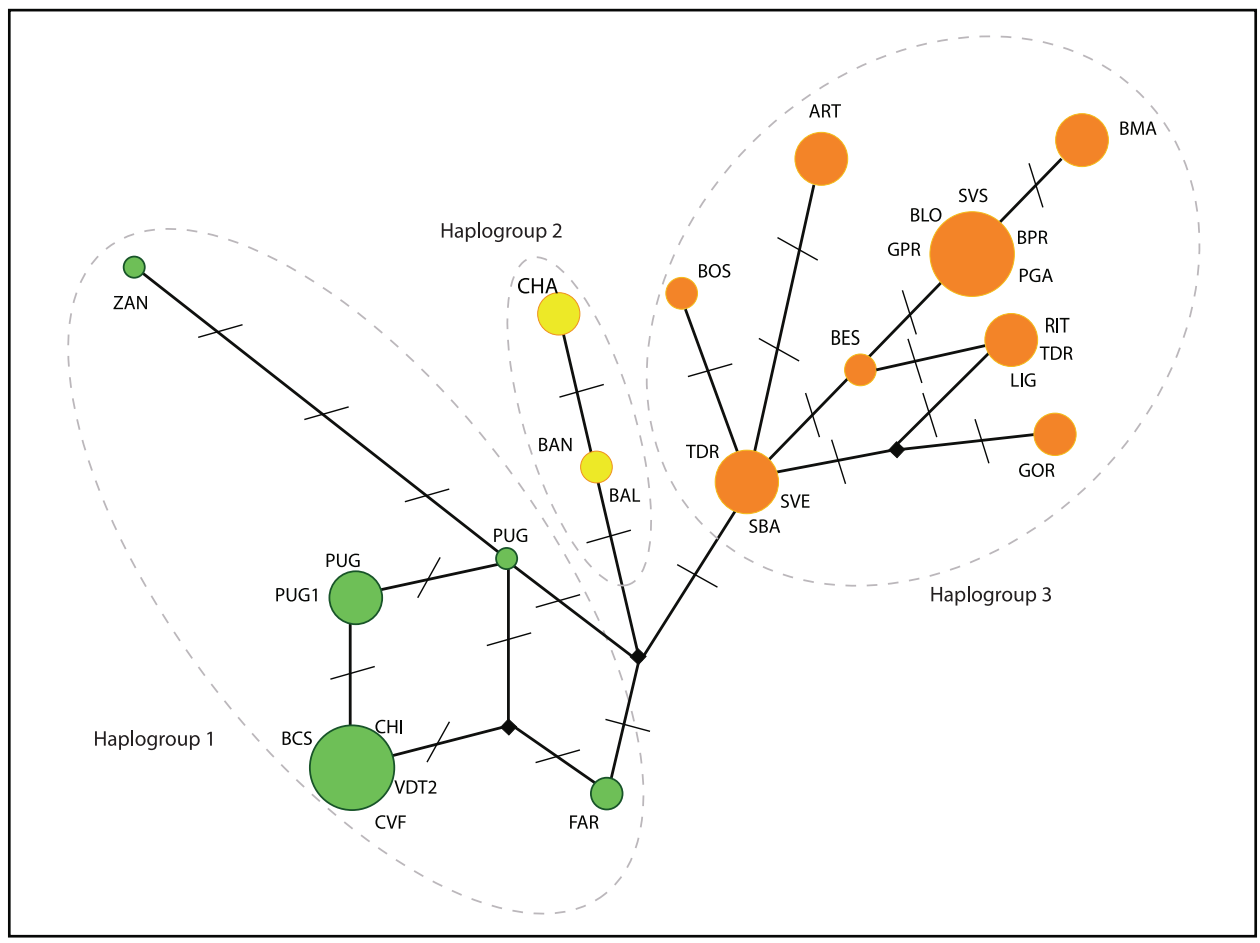

Figure 2. Median-joining network analysis in the populations of Dolichopoda considered in this study: circled areas are proportional to the number of individuals sharing the same haplotype; bars, along connections, indicate the number of nucleotide substitutions. Individuals from the same population can show different haplotypes. Based on number of nucleotide substitutions, three haplogroups can be distinguished, each indicated with different color.

ABGD analysis proposed several partitions that varied according to the different a priori thresholds. Apart from the two extreme a priori threshold values $(P=0.001$ and $P$ $=0.035$ ), for which aberrant number of species hypotheses were obtained (almost every haplotype was considered as a different species hypothesis for $P=0.001$ and, conversely, all the haplotypes were combined in a single species hypothesis for $P=0.035$ ), all the tested a priori thresholds lead to the same splitting. The westernmost Dolichopoda taxa were grouped together, while the other groups corresponded to the nominal species.

Analysis of molecular variance (AMOVA; Excoffier et al. 1992) used to measure the proportion of genetic variation among subdivided populations, suggested a strong structure within the populations $\left(F_{\mathrm{ST}}=0.979, P=0\right)$. Genetic variation among different geographic groups and among populations within each group was $52.16 \%$ and 45.8 $\%$, respectively, with $F_{\mathrm{CT}}=0.522(P=0)$ and $F_{\mathrm{SC}}=0.957(P=0)$. Mantel test suggested a clear isolation by distance across the sampled region $\left(\mathrm{R}^{2}=0.623, P \leq 0.002\right)$. 


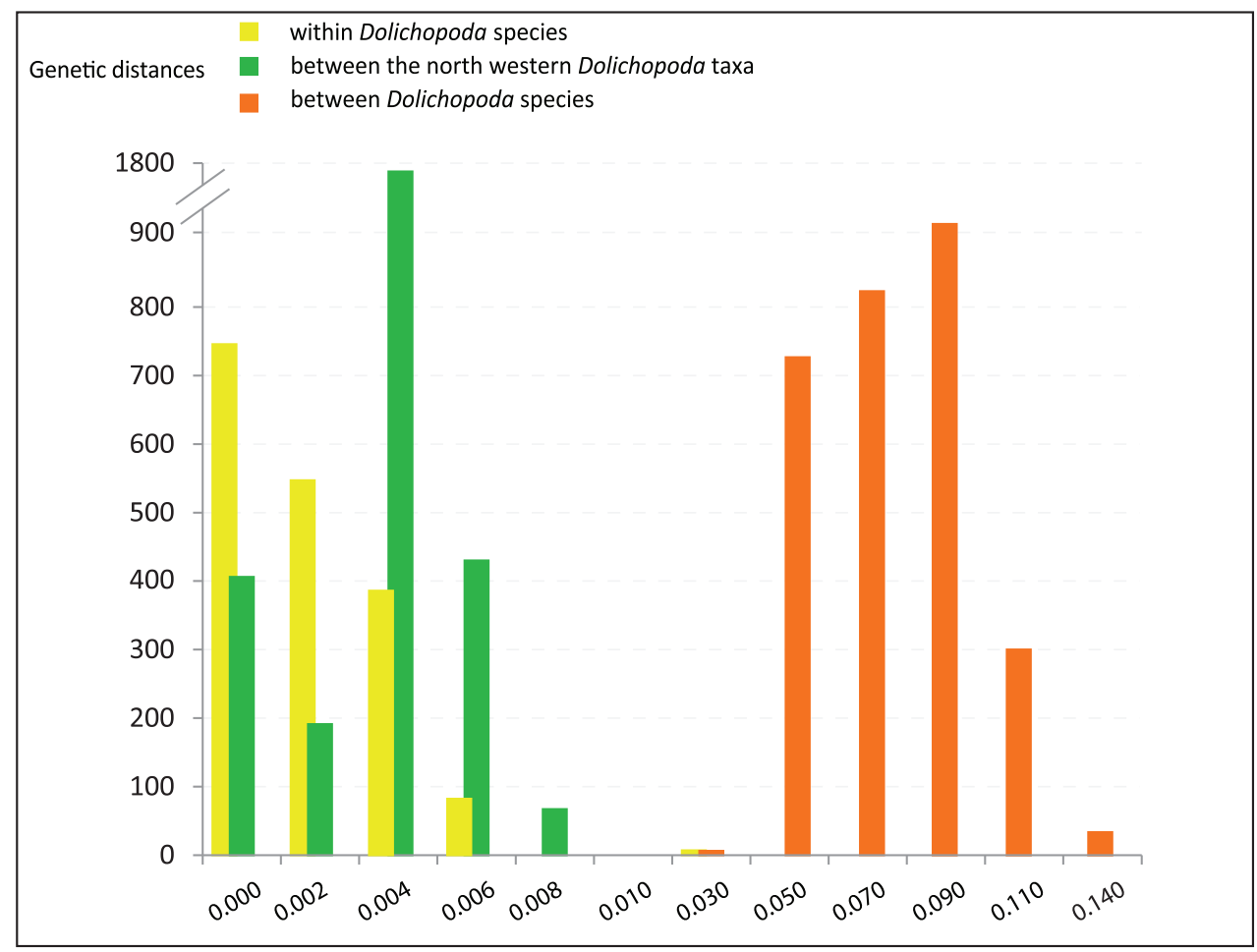

Figure 3. Distribution of genetic distance values (p-distances) at different taxonomic levels. Pairwise comparisons at the intra- and inter-specific level in all Dolichopoda species are reported.

\section{Phylogenetic analysis}

MRMODELTEST (Nylander 2004) indicated GTR + I + G (Lanave et al. 1984; Gu et al. 1995) and K80 + I (Kimura 1980) as the best models of DNA substitution for the mitochondrial genes and the nuclear one, respectively. The phylogeny in Figure 4 supports the major phylogenetic relationships previously demonstrated (Allegrucci et al. 2005, 2011; Martinsen et al. 2009). The Italian Dolichopoda species are separated in two main clusters, as expected. The first group included the continental species from Liguria to southern Italy (D. ligustica, D. l. septentrionalis, D. azami, D. laetitiae and $D$. geniculata). Populations from D. ligustica, D. l. septentrionalis, and D. azami constituted a homogeneous clade well differentiated from $D$. laetitiae and D. geniculata. The second group was represented by the southernmost species from Tuscany, to Corsica, Campania and Calabria (i.e., D. aegilion, D. baccettii, D. schiavazzii, D. cyrnensis, D. bormansi and D. muceddai and D. palpata with its sister taxon D. capraensis). Linked to these clusters are $D$. linderi and $D$. bolivari. 


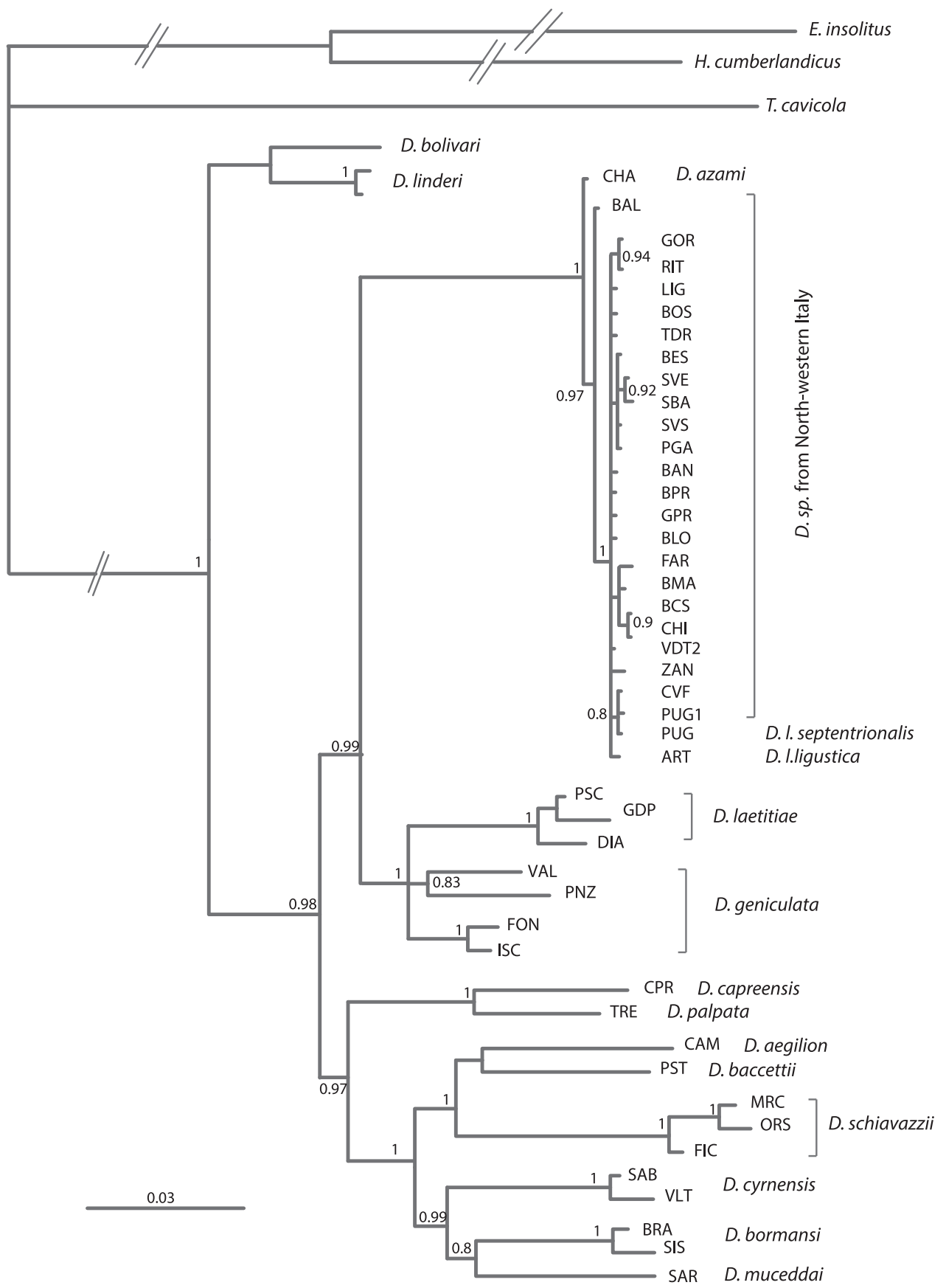

Figure 4. Relationships among Italian species of Dolichopoda inferred from Bayesian analysis based on three mitochondrial and one nuclear genes. Values above branches indicate posterior probabilities derived from Bayesian analysis. Scale bars: 0.03 substitutions per site. Only posterior probability (PP) values $\geq$ 0.80 are shown. 


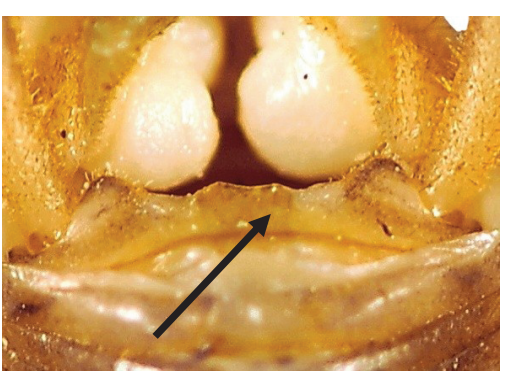

5

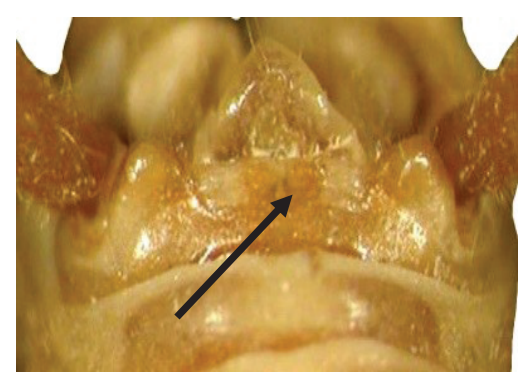

8

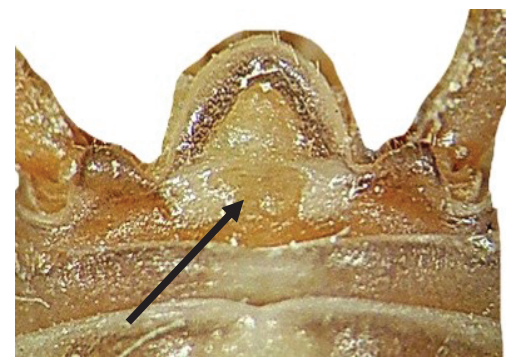

11

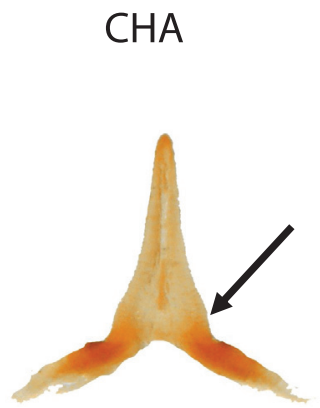

6

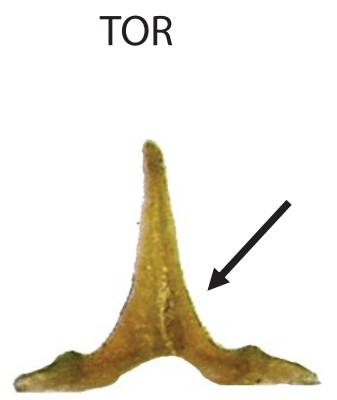

9

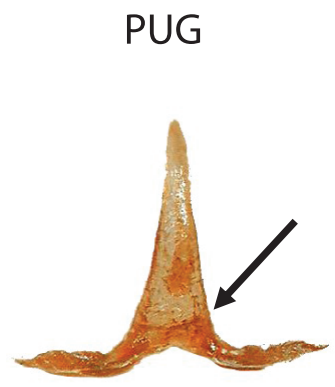

12

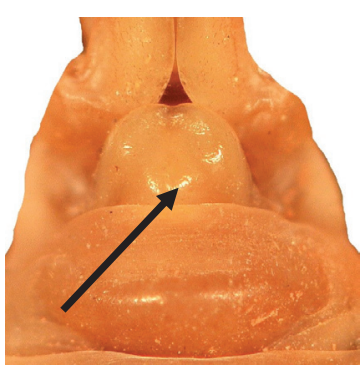

7

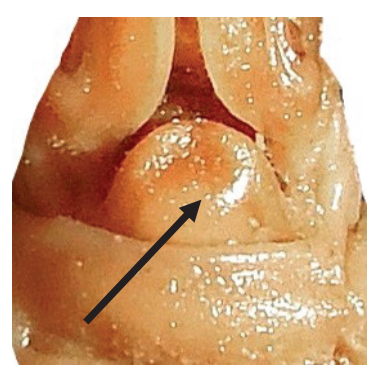

10

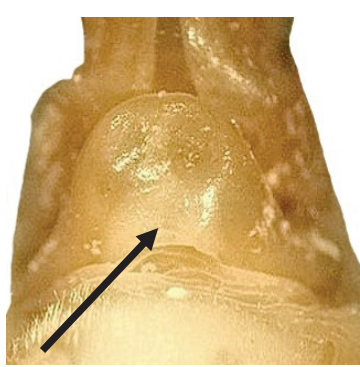

13

Figures 5-13. Morphological characters of Dolichopoda azami (CHA type locality), Dolichopoda l. ligustica (TOR type locality) and Dolichopoda l. septentrionalis (PUG type locality). Left: dorsal view of tergum 10; centre: epiphallus of the male; right: particular of the female sub-genital plate. Arrows show diagnostic characters.

\section{Morphological analysis}

In Figures 5-13 morphological comparisons among the three samples from the typical locality of D. azami (Chateaudouble, CHA), D. ligustica (Toirano, TOR) and D. l. septentrionalis (Pugnetto, PUG) are reported. In these figures, the three main characters are compared: male tergum 10, epiphallus and female sub-genital plate. The other two con- 


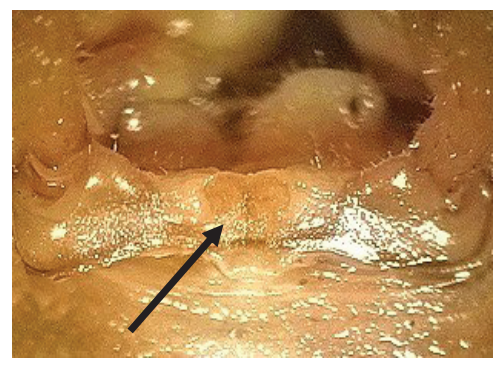

14

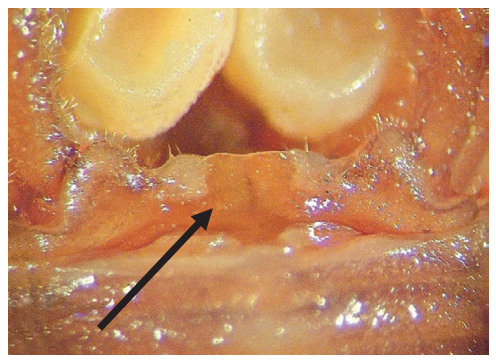

17

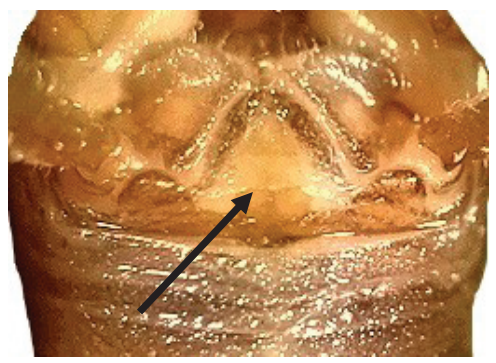

20

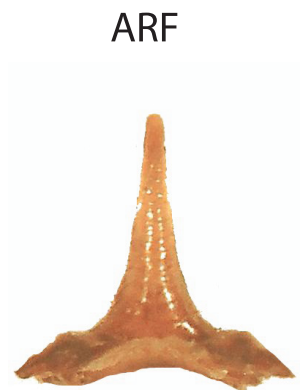

15

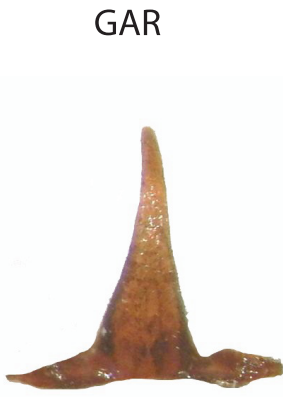

18

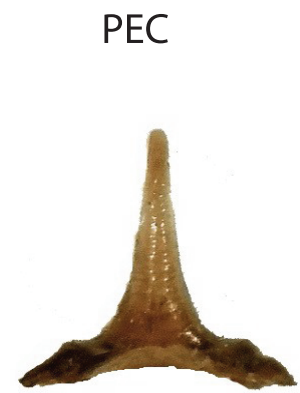

21

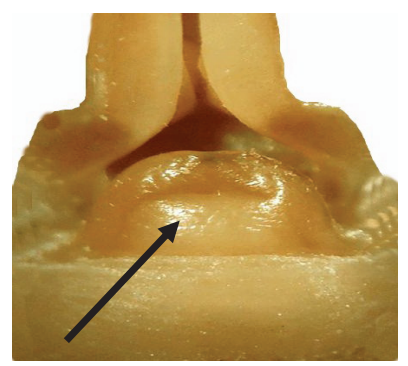

16

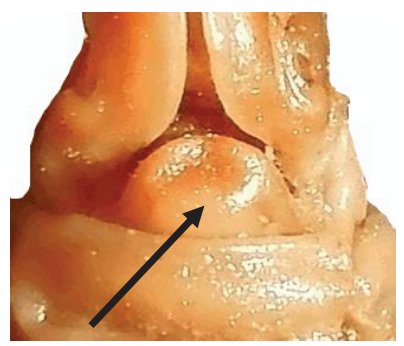

19

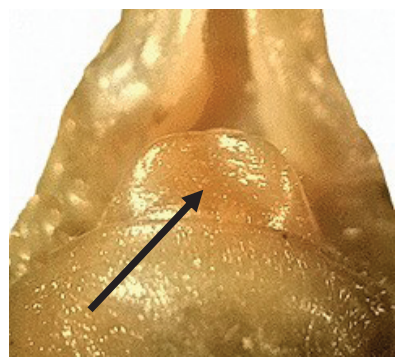

22

Figures 14-22. Morphological characters of the Dolichopoda from Liguria: ARF, GAR and PEC. Left: dorsal view of tergum 10; centre: epiphallus of the male; right: particular of the female sub-genital plate. Arrows show diagnostic characters.

sidered morphological features, male sub-genital plate and ovipositor, are not reported because showed a very uniform pattern. As already evidenced in the taxonomic revision of the genus Dolichopoda (Baccetti and Capra 1959), it is possible to distinguish the species D. azami through the male tergum 10 that shows two rounded lobes separated by a large concavity with two little acuminate tips (Fig. 5) and median process of the epiphallus enlarged at the basis (Fig. 6). In the female, the sub-genital plate is completely 


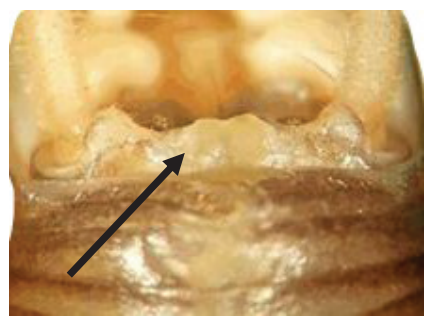

23

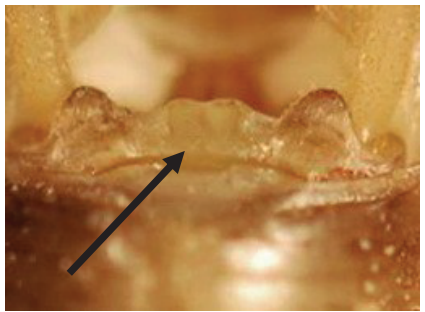

26

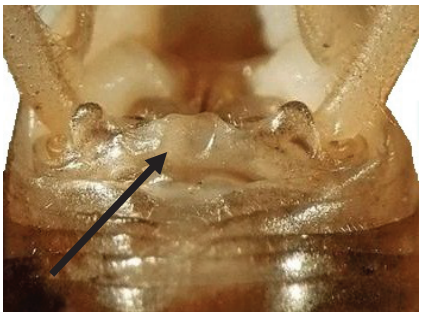

29

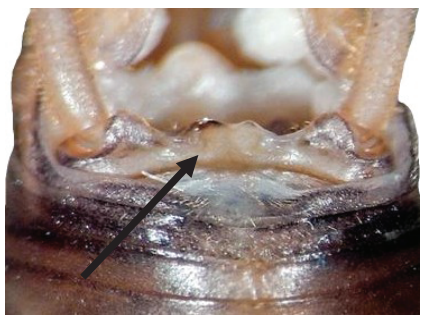

32

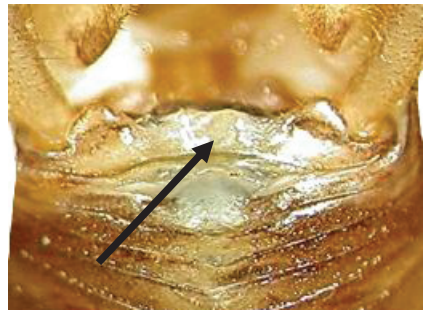

35

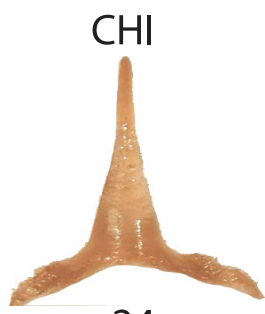

24

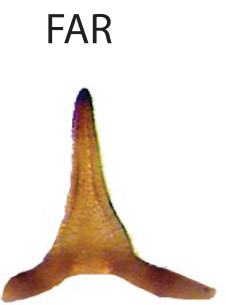

27

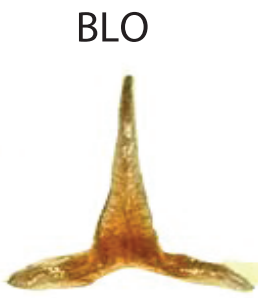

30

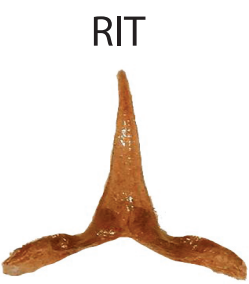

33

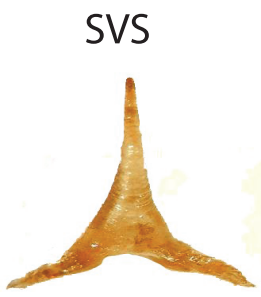

36

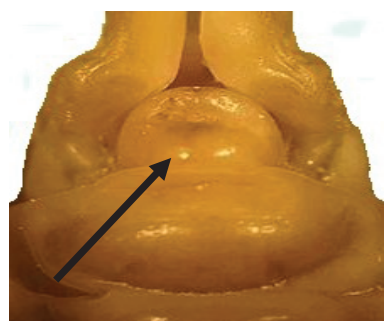

25

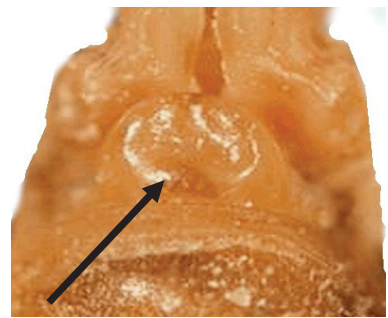

28

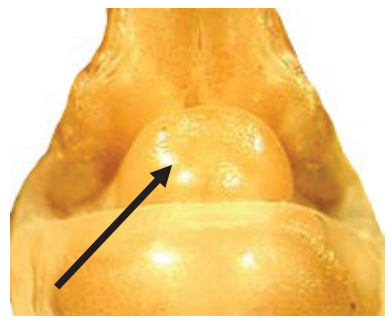

31

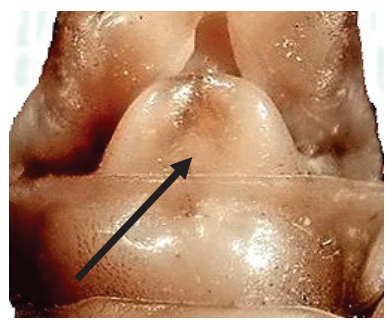

34

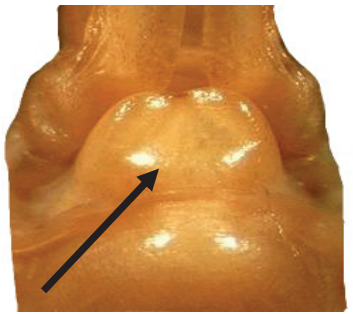

37

Figures 23-37. Morphological characters of the Dolichopoda from Piedmont: CHI, FAR, BLO, RIT and SVS. Left: dorsal view of tergum 10; centre: epiphallus of the male; right: detail of the female subgenital plate. Arrows show diagnostic characters. 
rounded with a narrow apical incision (Fig. 7). On the contrary, D. ligustica shows a male tergum 10 with little oval lobes separated by almost straight margin (Fig. 8), and median process of epiphallus pyramidal with lateral margin almost straight (Fig. 9). The female sub-genital plate is very similar to that of D. azami (Fig. 10) but the median incision appears less pronounced. Finally, the subspecies $D$. l. septentrionalis is distinguishable only for the more slender median process of the epiphallus (Fig. 12). Based on these observations, it is evident the great similarity of the three taxa here considered and consequently the strong difficulty in their morphological distinction.

In Figures 14-22, we compared three samples from western Liguria (Table 1). The three considered characters appear uniform resembling all to the morphology of TOR (Figs 8-10) the typical D. ligustica. On the contrary, the analysis of a series of samples from northern and southern Piedmont (Figs 23-37) highlights a more complex situation with the contemporary presence of characters typical of one or the other species in the same individual. In particular, even if all the specimens analyzed show the tergum 10 very similar to that of D. azami (cfr Fig. 5 with Figs 23, 26, 29, 32, 35) the same specimens often show the shape of epiphallus and of the female sub-genital plate more similar to that of $D$. ligustica.

In Table 3, the measures of 12 morphological characters, recorded on 6 populations, where a sufficient number of adults were available, are reported. Mann-Whitney test carried out between males and females morphometric traits revealed significant differences $(P<0.05)$, being the females smaller than males. ANOVA analysis highlighted significant differences between some morphometric measures in specimens coming from caves situated at different altitude both in males and in females. Multiple regression analysis revealed a significant correlation between the morphometric measures and the altitude of the cave $\left(\mathrm{R}^{2}=0.661\right.$, Wilk's lbd $\left.=0.0045 ; P<<0.01\right)$. In particular, samples coming from caves at low altitudes resulted bigger than those from caves at higher altitudes.

\section{Discussion}

The Northwestern Italian Dolichopoda species group comprises a uniform assemblage of populations, both genetically and morphologically. From genetically point of view, the median joining network analysis (Fig. 2) evidenced three main haplogroups geographically distributed, but the resulting scenario is rather homogeneous with a maximum number of mutation events equal to 8 . Genetic distance values based on COI gene revealed a very little differentiation between all studied samples. All pairwise comparisons fall in the range of intraspecific comparisons observed in all the other Dolichopoda species, with a mean of $0.3 \%$ (Fig. 3). These results suggest a level of differentiation usually found between populations belonging to the same species rather than to different species. ABGD analysis confirms these results, grouping together all the northwestern Dolichopoda taxa.

However, despite the low variability, these populations show a significant level of genetic structure. Indeed, AMOVA analysis evidenced significant partitioning of 
variation within and among populations and among regions and a low level of gene flow between the different regions. Isolation by distance was also detected by Mantel test, suggesting that dispersal rates in these Dolichopoda populations are very low and limited to the geographically close ones. This result is not surprising for cave dwelling organisms because it reflects the geographic isolation of the different caves and / or groups of caves to which Dolichopoda populations are confined (Sbordoni et al. 2012). The Maritime Alps region is characterized by a combination of Mediterranean, Apennine and Alpine flora and this diversity in habitat geography could strongly influence the different degree of isolation of the Dolichopoda populations. While the presence of beech and oak forests would account for continuing gene flow among Dolichopoda species, the occurrence of Alpine forests and to some extent of the Mediterranean "macchia" could prevent the gene exchange (Allegrucci et al. 1997; Sbordoni et al. 1985, 2012).

The phylogeny illustrated in Figure 4, based on three mitochondrial (COI, $12 \mathrm{~S}$ and $16 \mathrm{~S}$ ) and one nuclear (28S) genes, supports the major phylogenetic relationships previously demonstrated (Allegrucci et al. 2005, 2011) highlighting that the northwestern Italian populations represent a single, uniform, well supported cluster. With respect to the other Italian species, they are genetically very similar, showing very short branch lengths and forming a single cluster in which the relationships between the different populations are not clearly resolved. Based on previous studies carried out on the $90 \%$ of the species belonging to genus Dolichopoda (Allegrucci et al. 2005, 2011), we know that divergence time between these populations and their sister taxon, represented by the cluster $D$. laetitiae- $D$. geniculata, is dated back to about 2 Million years ago, during the late Pliocene. In that time, the western Mediterranean lineages probably arose from a single colonization event from the North of Italy. An ancestral group spread in two directions, colonizing on one hand Piedmont, Liguria and France and, on the other side, the entire inland of Italian Peninsula.

The morphological analysis shows high degree of similarity between all analyzed samples, suggesting that the morphological traits commonly used in the taxonomy of the genus Dolichopoda (tergum 10, epiphallus shape in the male and sub-genital plate in the female), are not able to discriminate clearly specimens belonging to D. azami, D. ligustica and D. l. septentrionalis. In particular, although very few morphological differences can be observed between specimens from the typical localities of the three taxa (CHA, typ. loc. of D. azami; TOR, typ. loc. of D. ligustica and PUG, typ. loc. of $D$. l. septentrionalis), the most of the studied samples show some variability in the diagnostic characters occurring more or less randomly. Often we observed in the same specimen, the contemporary presence of characters typical of one or the other taxon.

Morphometric analysis suggested significant differences both between males and females and between samples from caves situated at different altitudes. Caves situated at high altitude are presumably subjected at lower temperatures and therefore the bioclimatic factors may be the major determinants of the morphometric patterns observed. Morphological traits might be subjected to substantial non-genetic variation and/or might show local short-term adaptations to peculiar environmental conditions. 
These differences were already been observed in populations of $D$. laetitiae and $D$. geniculata in the central southern Italy (Allegrucci et al. 1987; Cesaroni et al. 1997). In those studies, we demonstrated that variations in morphometric measures (and in particular in leg elongation) is almost entirely under the control of an environmental gradient, synthetically described by the cave temperature.

In conclusion, the scenario, depicted by both molecular markers and morphological traits, suggests that the northwestern Italian Dolichopoda constitute a single species with populations characterized from high similarity between each other and, due to the priority of description, they should be assigned to D. azami Saulcy, 1893 which is the older available name at the species rank. However, in order to portrait the geographical partitioning and the related genetic differences we suggest to preserve the names ligustica Baccetti \& Capra, 1959 and septentrionalis Baccetti \& Capra, 1959 to indicate groups of populations corresponding to the different COI haplogroups as outlined in the network analysis (Fig. 2).

Therefore, the new taxonomic arrangement here proposed is:

D. azami azami Saulcy, 1893

Type locality. Mine close to Chauves-souris Cave, Chateaudouble, Var, France, $525 \mathrm{~m}$ asl;

D. azami ligustica Baccetti \& Capra, 1959, stat. n.

Type locality. Santa Lucia Inferiore Cave, Toirano, SV, Liguria, 194 m asl;

D. azami septentrionalis Baccetti \& Capra, 1959, stat. $\mathrm{n}$.

Type locality. Borna Maggiore del Pugnetto Cave, Mezzenile, Lanzo Valley, TO, Piedmont, $820 \mathrm{~m}$ asl.

\section{Acknowledgements}

This paper would not have been possible without the help of friends and colleagues who provided us the studied samples. A special thanks to Roberto Poggi (Civic Museum of Natural History "G. Doria" of Genoa), who allowed us to access to the Museum's collections, and gave to one of us (MR) useful suggestions. Stefano De Felici helped us in in the implementation of Figure 1.

\section{References}

Allegrucci G, Cesaroni D, Sbordoni V (1987) Adaptation and speciation of Dolichopoda cave crickets (Orthoptera, Rhaphidophoridae) geographic variation of morphometric indices and allozyme frequencies. Biological Journal of Linnean Society 31: 151-160. doi: 10.1111/j.1095-8312.1987.tb01986.x 
Allegrucci G, Minasi MG, Sbordoni V (1997) Patterns of gene flow and genetic structure in cave-dwelling crickets of the Tuscan endemic, Dolichopoda schiavazzii (Orthoptera, Rhaphidophoridae). Heredity 78: 665-673. doi: 10.1038/hdy.1997.106

Allegrucci G, Todisco V, Sbordoni V (2005) Molecular phylogeography of Dolichopoda cave crickets (Orthoptera, Rhaphidophoridae): a scenario suggested by mitochondrial DNA. Molecular Phylogenetics and Evolution 37: 153-164. doi: 10.1016/j.ympev.2005.04.022 Allegrucci G, Rampini M, Gratton P, Todisco V, Sbordoni V (2009) Testing phylogenetic hypotheses for reconstructing the evolutionary history of Dolichopoda cave crickets in the eastern Mediterranean. Journal of Biogeography 36: 1785-1797. doi: 10.1111/j.1365-2699.2009.02130.x

Allegrucci G, Trucchi E, Sbordoni V (2011) Tempo and mode of species diversification in Dolichopoda cave crickets (Orthoptera, Rhaphidophoridae). Molecular Phylogenetics and Evolution 60: 108-121. doi: 10.1016/j.ympev.2011.04.002

Azam J (1893) Listes des Orthoptères de Hautes et Basses-Alpes. Annales de la Sociétè entomologique de France 62: 196-198. (Dolichopoda azami Saulcy in Azam 1893)

Baccetti B (1966) Notulae Orthopterologicae XXI, Le Dolichopoda della Francia e della Spagna. International Journal of Speleology 2: 17-28. doi: 10.5038/1827-806X.2.1.3

Baccetti B (1975) Notulae orthopterologicae. XXXII. Una nuova specie di Dolichopoda raccolta sull'Isola del Giglio. Bollettino Istituto Entomologico Università di Bologna 31: 205-214.

Baccetti B, Capra F (1959) Notulae Orthopterologicae. XII. Revisione delle specie italiane del genere Dolichopoda Bol.(Orth. Rhaph.). Redia 44: 165-217.

Baccetti B, Capra F (1970) Notulae Orthopterologicae. XXVII. Nuove osservazioni sistematiche su alcune Dolichopoda italiane esaminate anche al microscopio elettronico a scansione. Memorie Società Entomologica Itaiana 48: 351-367.

Bandelt HJ, Forster P, Rohl A (1999) Median-joining networks for inferring intraspecific phylogenies. Molecular Biology and Evolution 16: 37-48. doi: 10.1093/oxfordjournals. molbev.a026036

Carchini G, Rampini M, Severini C, Sbordoni V (1983) Population size estimates of four species of Dolichopoda in natural and artificial caves of Central Italy (Orth. Raph.). Mémorie du Biospéologie 10: 341-347.

Cesaroni D, Matarazzo P, Allegrucci G, Sbordoni V (1997) Comparing patterns of geographic variation in cave crickets by combining geostatistic methods and Mantel tests. Journal of Biogeography 24: 419-431. doi: 10.1111/j.1365-2699.1997.00104.x

Chopard L (1951) Faune de France. Orthoptèroides (Paris) 56: 1-359.

Di Russo C, Rampini M, Landeck I (2007) The cave crickets of North-East Turkey and TransCausasian regions, with description of two new species of the genera Dolichopoda and Troglophilus (Orthoptera, Rhaphidophoridae). Journal of Orthoptera Research 16: 67-76. doi: 10.1665/1082-6467(2007)16[67:TCCONT]2.0.CO;2

Di Russo C, Rampini M (2014) New record of Dolichopoda from Northern Iran. (Orthoptera, Rhaphidophoridae) Fragmenta entomologica 45: 1-3.

Excoffier L, Smouse PE, Quattro JM (1992) Analysis of molecular variance inferred from metric distances among DNA haplotypes: application to human mitochondrial DNA restriction data. Genetics 131: 479-491. 
Excoffier L, Laval G, Schneider S (2005) Arlequin .version 3.0.: an integrated software package for population genetics data analysis. Evolutionary Bioinformatics Online 1: 47-50.

Finot A (1890) Faune de France. Insectes Orthoptères. Thysanoures et Orthoptères proprement dits. Deyrolle, Paris, in-8, 322 pp.

Folmer O, Black MB, Hoch W, Lutz RA, Vrijehock RC (1994) DNA primers for amplification of mitochondrial Cytochrome c Oxidase subunit I from diverse metazoan invertebrates. Molecular Marine Biology and Biotechnology 3: 294-299.

Friedrich M, Tautz D (1997) An episodic change of rDNA nucleotide substitution rate has occurred during the emergence of the insect order Diptera. Molecular Biology and Evolution 14: 644-653. doi: 10.1093/oxfordjournals.molbev.a025804

Gu X, Fu YX, Li WH (1995) Maximum likelihood estimation of heterogeneity of substitution rate among nucleotide sites. Molecular Biology and Evolution 12: 546-557.

Hebert PDN, Cywinska A, Ball SL, deWaard JR (2003) Biological identifications through DNA barcodes. Proceedings of the Royal Society of London B 270: 313-321. doi: 10.1098/rspb.2002.2218

Huelsenbeck JP, Ronquist F (2001) MrBayes: Bayesian inference of phylogenetic trees. Bioinformatics 17: 754-755. doi: 10.1093/bioinformatics/17.8.754

Kimura M (1980) A simple method for estimating evolutionary rates of base substitutions through comparative studies of nucleotide sequences. Journal of Molecular Evolution 16: 111-120. doi: 10.1007/BF01731581

Kocher TD, Thomas WK, Meyer A, Edwards SV, Paabo S, Villablanca FX, Wilson AC (1989) Dynamics of mitochondrial DNA evolution in animals: Amplification and sequencing with conserved primers. Proceedings of the National Academy of Sciences of the United States of America 86: 6196-6200. doi: 10.1073/pnas.86.16.6196

Lanave C, Preparata C, Saccone C, Serio G (1984) A new method for calculating evolutionary substitution rates. Journal of Molecular Evolution 20: 86-93. doi: 10.1007/BF02101990

Lunt DH, Zhang DX, Szymura JM, Hewitt GM (1996) The insect cytochromo oxidase I gene: evolutionary patterns and conserved primers for phylogenetic studies. Insect Molecular Biology 5: 153-165. doi: 10.1111/j.1365-2583.1996.tb00049.x

Mantel N (1967) The detection of disease clustering and a generalized regression approach. Cancer Research 27: 209-220.

Martinsen L, Venanzetti F, Johnsen A, Bachmann L (2009) Phylogeography and mitochondrial DNA divergence in Dolichopoda cave crickets (Orthoptera, Rhaphidophoridae). Hereditas 146: 33-45. doi: 10.1111/j.1601-5223.2008.02068.x

Nylander JAA (2004) MrModeltest v.2. Program distributed by the author. Evolutionary Biology Centre, Uppsala University.

Puillandre N, Lambert A, Brouillet S, Achaz G (2012) ABGD, Automatic Barcode Gap Discovery for primary species delimitation. Molecular Ecology 21: 1864-1877. doi: 10.1111/j.1365-294X.2011.05239.x

Rozas J, Sanchez-DelBarrio JC, Messeguer X, Rozas R (2003) DnaSP, DNA plymorphism analyses by the coalescent and other methods. Bioinformatics 19: 2496-2497. doi: 10.1093/bioinformatics/btg359 
Sbordoni V, Allegrucci G, Cesaroni D, Cobolli Sbordoni M, De Matthaeis E (1985) Genetic structure of populations and species of Dolichopoda cave crickets: evidence of peripatric divergence. In: Sbordoni V (Ed) Genetics and ecology in contact zones of populations. Boll. Zool. 52: 95-114.

Sbordoni V, Allegrucci G, Caccone A, Carchini G, Cesaroni D (1987) Microevolutionary studies in Dolichopodinae cave crickets. In: Baccetti B (Ed) Evolutionary Biology of Orthopteroid Insects. Horwood Ltd. Publ., Chichester, UK, 514-540.

Sbordoni V, Allegrucci G, Cesaroni D (2012) Population Structure. In: White WB, Culver DC (Eds) Encyclopedia of Caves. Academic Press, Chennai, 608-618. doi: 10.1016/ B978-0-12-383832-2.00090-6

Simon C, Frati F, Beckenbach A, Crespi B, Liu H, Flook P (1994) Evolution, weighting and phylogenetic utility of mitochondrial gene sequences and a compilation of conserved polymerase chain reaction primers. Annals of Entomological Society of America 87: 651-701.

Slatkin M (1993) Isolation by distance in equilibrium and nonequilibrium populations. Evolution 47: 264-279. doi: 10.2307/2410134

Tamura K, Dudley J, Nei M, Kumar S (2007) MEGA4: molecular evolutionary genetics analysis. MEGA. software version 4.0. Molecular Biology and Evolution 24: 1596-1599. doi: $10.1093 / \mathrm{molbev} / \mathrm{msm} 092$

Thompson JD, Gibson TJ, Plewniak F, Jeanmougin F, Higgins DG (1997) The ClustalX windows interface: flexible strategies for multiple sequence alignment aided by quality analysis tools. Nucleic Acids Research 24: 4876-4882. doi: 10.1093/nar/25.24.4876

Weir BS (1996) Genetic Data Analysis. Sinauer Associates, Sunderland, MA.

Weir BS, Cockerham CC (1984) Estimating F-statistics for the analysis of population structure. Evolution 38: 1358-1370. doi: 10.2307/2408641

Wright S (1943) Isolation by distance. Genetics 28: 114-138.

Wright S (1951) The genetical structure of populations. Annals of Human Genetics 15: 323-354. 